\section{AN UNKNOWN CORRELATION IN HEXAMETRIC POETRY AND THE INTERPRETATION OF THE BREVIS IN LONGO PRINCIPLE}

\begin{abstract}
Alejandro Abritta*
RESUMEN: El objetivo de este artículo es mostrar que (algunos) poetas hexamétricos de la Grecia Antigua no eran indiferentes a la cantidad de la sílaba final del verso, estudiando la correlación entre esa cantidad y los diferentes finales de palabra posibles en el cuarto pie del verso. Los resultados del estudio sugieren que en algunos poetas había una cierta preferencia por la "coherencia rítmica" en el segundo colon, lo que indica que, incluso si había una "indiferencia composicional" respecto a la cantidad de la última sílaba, no había "indiferencia efectiva".
\end{abstract}

PALABRAS CLAVE: Hexámetro dactílico; Brevis in Longo; Métrica griega antigua; diéresis bucólica; cesura heptemímera; Homero; Apolonio de Rodas; Nono.

\section{UNA CORRELACIÓN DESCONOCIDA EN LA POESÍA HEXAMÉTRICA Y LA INTERPRETACIÓN DEL PRINCIPIO BREVIS IN LONGO}

* Becario de investigación del Instituto de Filología Clásica, Facultad de Filosofía y Letras, Universidad de Buenos Aires - Conicet. alejandroabritta88@ yahoo.com.ar

\begin{abstract}
The goal of this paper is to show that (some) Ancient Greek hexametric poets were not indifferent to the quantity of the final syllable of the verse, by studying the correlation between that quantity and the different possible word ends in the fourth foot of the verse. The results of the study suggest that in some poets there was a certain preference for "rhythmic coherence" within the second colon, which indicates that, even if there was "compositional indifference" regarding the quantity of the last syllable, there was not "actual indifference".
\end{abstract}

KEYWORDS: Dactylic Hexameter; Brevis in Longo; Ancient Greek Metrics; Bucolic Diaeresis; Hepthemimeral Caesura; Homer; Apollonius Rhodius; Nonnus. 


\section{INTRODUCTION}

The final syllable of the dactylic hexameter has been traditionally left aside in the quantitative analysis of the metre. ${ }^{1}$ For the most part, scholars have assumed that its alleged "indifference" meant that the number of long and short vowels (or heavy and light syllables, see below) in the last location of the line was merely a product of chance, since poets did not care about the quantity of the final syllable. This has led to a universal disregard for the data regarding the sixth foot of Archaic and Hellenistic hexameter in basically all statistical studies. It is only when we get to Nonnus that the final syllable seems to start to matter, allegedly because of the influence of the disappearance of quantitative oppositions in the language. ${ }^{2}$

This paper will present data that suggest that some poets paid attention to the quantity of the final syllable of the hexameter since Homer. ${ }^{3}$ It will not convince many scholars that such an extended methodological principle as the actual indifference (see below on "actual" vs. "compositional" indifference) of the final syllable is incorrect. However, I hope it will suffice to at least cast some doubt on its up until now mostly unquestioned validity.

\section{BREVIS IN LONGO}

There are two connected but independent problems when studying the final syllable of the hexameter. First, whether poets and listeners (or readers) of hexametric poetry cared about or even noticed the quantitative oppositions at the end of the line. Second, if they cared, which syllables were considered heavy and which syllables were considered light. ${ }^{5}$

\footnotetext{
${ }^{1}$ E.g. in O’Neill (1942) or Van Raalte (1986). O’Neill, however, provides information about the quantity of the final syllable in his corpus in his table 29.

${ }^{2}$ See Maas (1962, 16-17) and Magnelli (2016, 361-63, with numerous references). See also Allen (1967, 59-60), with a different (though not completely different) explanation of the data.

${ }^{3} \mathrm{I}$ have used the samples and analysis systems published in <https://greekmps.wordpress.com>. The reader can check the editions used and the exact composition of each sample in the documents available in <https://greekmps.wordpress.com/data-and-tools/samples>.

${ }^{4}$ I will use brevis in longo as if it simply meant that the poets could place both light and heavy syllables at the end of the line. That will allow avoiding "indifference", which is a word I rather reserve for the interpretations of the principle. Note that "brevis in longo" usually means "a short syllable followed by a rest that makes up the time of a long" (Leedy 2014, 8), that is, it involves only one aspect of the indifference and its phonetic explanation. In my use, the term covers the general phenomenon and says nothing about its explanation.

${ }^{5}$ Since there are two different "quantities" involved here (vocalic and syllabic), I will use the dual terminology introduced by Allen (1973, 53-55): "heavy" and "light" are used for syllabic quantity (that is, $(\mathrm{C}) \mathrm{VV}(\mathrm{C})$ and $(\mathrm{C}) \mathrm{VC}$ vs. $(\mathrm{C}) \mathrm{V}$ ) and "long" and "short" for vocalic quantity (that is, $(\mathrm{C}) \mathrm{VV}(\mathrm{C})$ vs. (C) $\mathrm{V}(\mathrm{C})$ ).
} 
The first problem must be dealt with axiomatically, given the fact that we have no direct evidence to solve it. ${ }^{6}$ Since it is an unquestionable fact that poets could place at the end of the verse either heavy or light syllables (not only in hexameters and not only in Ancient Greek poetry), the question is if this indifference was "actual", meaning that the listeners or readers were actually unaware of the opposition or at least that they did not care about it, ${ }^{7}$ or "compositional", meaning that the poets could place either heavy or light syllables at the end of the line, but the listeners or readers noted the difference. In the first case, we would expect not to find evidence of a preference in the quantity of the final syllable at all; if we found such a preference, we would seek an explanation that did not depend on the actual quantity of the syllable. In the second case, we would not be surprised if we found some tendency in the distribution of quantities in the final location of the verse; if, on the other hand, we found no evidence of a preference, we would assume that the compositional indifference has led to metrical indifference, which is not uncommon in other locations. In this case, the quantity of the final syllable would be analogous to phenomena like Bulloch's bridge in Homer, which is not an active rule. ${ }^{8}$

The second problem is much more complicated, since it determines how we must analyse the data. Some scholars consider that syllables at the end of the verse ending in a consonant should be considered heavy, as if they were closed. ${ }^{9}$ Other scholars consider that at the end of the verse those syllables should be considered light, since there is no following consonant to close the syllable. ${ }^{10}$ Nobody (actual indifference of the final location apart)

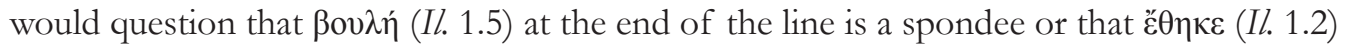
at the end of the line is a trochaic ending word; the problem is how should we count a word like A $\chi \imath \lambda \tilde{\eta} о \varsigma$ (Il. 1.1).

I have decided that the best strategy is not to solve the problem, but to analyse the data in both scenarios. Fortunately, with the system used in this study, this is not only possible but actually rather simple. Given that the results will vary sometimes from one scenario to another, I will analyse each group of outcomes, and leave to the reader the ultimate decision on which one should be accepted. ${ }^{11}$

\footnotetext{
${ }^{6}$ However, we do have indirect evidence (see Quint. 9.4.93 and Luque Moreno 2005, 119n19).

${ }^{7}$ A position explicitly held by Nagy $(1990,439-40)$ and implied in the extended notation "_" for the final syllable in textbooks like Maas (1962), Korzeniewski (1968), West (1982) and Sicking (1993).

8 "When the hexameter of Callimachus has word boundary after 3 rd biceps, it must have not only regular caesura but also a bucolic diaeresis" and there has to be a syntactic break "at either the caesura or the bucolic diaeresis or both" (Devine and Stephens 1984, 12). The rule was presented in Bulloch (1970). ${ }^{9}$ Irigoin (1967), followed by Allen (1973, 204-207).

${ }^{10}$ See Dale $(1964,20$ n9).

11 There is a third possible interpretation that I will not consider here. Given that Ryan (2011) has recently demonstrated that the Homeric hexameter was sensible to multiple levels of syllabic quantity (though I disagree with the interpretation of the data he provides regarding the longum:biceps ratio), it might be that this also applied to the final syllable. In that case, correlations that oppose $(\mathrm{C}) \mathrm{V}(\mathrm{C})$ to $(\mathrm{C}) \mathrm{VV}(\mathrm{C})$ could be considered correlations of "vocalic quantity" and correlations that oppose $(\mathrm{C}) \mathrm{V}$ to $(\mathrm{C}) \mathrm{VC}$ and $(\mathrm{C}) \mathrm{VV}(\mathrm{C})$, correlations of "syllabic quantity". Both types could coexist in the history of a metre and even within the same poet between different locations.
} 
Besides the problem of final "closed" syllables, there is the problem of final diphthongs, particularly with the light diphthongs $\alpha$ and ou. Here, I have used the same strategy of not solving the issue. With diphthongs, there are three alternatives; for two of them (the accentual determination of the quantity described in $<$ https://greekmps.wordpress. $\mathrm{com} /$ prosodical-bases/syllabic-structure-and-code/ $>$ and considering all diphthongs as heavy syllables) I have used an automated system of analysis. Except for the sample of Theocritus, ${ }^{12}$ I have also divided manually (that is, not using the automated system of analysis) between light diphthongs and heavy diphthongs. ${ }^{13}$

When the alternatives for final closed syllables and final diphthongs are put together, there are six different interpretations of the quantity of the final syllable to take into account. It would have been easier simply to reject most of them and choose one to conduct all tests, but in the absence of evidence I prefer to leave the decision to the reader. While the validity of the results is unquestionable (at least in principle) when the different scenarios show ample coherence, it depends fundamentally on the reader's opinion on the quantity of final syllables in the hexameter when there is no coherence.

Since I will be referring to the different interpretations constantly, table 1 presents them with a simple system of references:

\begin{tabular}{|l|l|}
\hline \multicolumn{1}{|c|}{ Interpretation of the final syllable } & Reference \\
\hline $\begin{array}{l}\text { Final closed syllables counted as light, accentually defined } \\
\text { quantity of diphthongs }\end{array}$ & Scenario A1 \\
\hline $\begin{array}{l}\text { Final closed syllables counted as heavy, accentually defined } \\
\text { diphthongs }\end{array}$ & Scenario B1 \\
\hline Final closed syllables light, all final diphthongs counted as heavy & Scenario A2 \\
\hline Final closed syllables heavy, all final diphthongs heavy & Scenario B2 \\
\hline Final closed syllables light, diphthongs with standard quantity & Scenario A3 \\
\hline Final closed syllables heavy, diphthongs with standard quantity & Scenario B3 \\
\hline
\end{tabular}

TABLE 1 - Interpretations of the quantity of the final syllable of the verse and references.

\section{Detecting Caesurae}

This paper will be concerned with the correlation between the presence of the bucolic diaeresis in a verse and the quantity of the final syllable. I have used (for the first part of the analysis) two possible oppositions in the fourth foot of the verse: presence vs. absence of bucolic diaeresis and presence of bucolic diaeresis vs. presence of hepthemimeral caesura.

Since I have used automated systems to detect caesurae, the results may differ from the ones that can be obtained by manually analyzing the verses. The system counts a

\footnotetext{
${ }^{12} \mathrm{I}$ have excluded Theocritus because of his numbers in the other four scenarios.

${ }^{13}$ See Smyth (1956, \$169): "final $-\alpha \mathrm{l}$ and $-0 \mathrm{l}$ are regarded as short (...). But in the optative [they] are long [and] also in the locative oíkor."
} 
bucolic diaeresis when there is a lexical word ending at the end of the fourth foot of the hexameter not followed by enclitic (see < https://greekmps.wordpress.com/prosodical-bases/ clisis $>$ for the meaning of "lexical" and "enclitic" here; the actual number is probably lower since the system is designed to detect accentual clisis and not rhythmic clisis). ${ }^{14}$ It counts a hepthemimeral caesura when there is a lexical word ending in the fourth longum of the verse not followed by enclitic and there is no lexical word ending at the end of the fourth foot (in other words, bucolic diaeresis trumps hepthemimeral, which is coherent with what we know about their frequencies in the hexameter). ${ }^{15}$ Note that the minor inconveniences that this system has should not affect the outcome of the analysis, given that what I will study is the correlation between the breaks in the fourth foot and the quantity of the final syllable, and if there is some deviation in the estimations it affects verses with heavy final syllable and light final syllable uniformly. In any case, table 2 presents the estimated percentages of caesurae in the fourth foot provided by the system:

\begin{tabular}{|l|r|r|r|r|}
\hline & Estimated bucolic & $\begin{array}{c}\text { Estimated } \\
\text { hepthemimeral }\end{array}$ & $\begin{array}{c}\text { Other } \\
\text { verses }\end{array}$ & $\begin{array}{c}\text { Total verses } \\
\text { analysed }\end{array}$ \\
\hline Iliad & $638(52.25 \%)$ & $358(29.32 \%)$ & $225(18.43 \%)$ & 1221 \\
\hline Odyssey & $677(53.60 \%)$ & $357(28.27 \%)$ & $229(18.13 \%)$ & 1263 \\
\hline Callimachus & $599(64.06 \%)$ & $180(19.25 \%)$ & $156(16.68 \%)$ & 935 \\
\hline Apollonius & $559(61.84 \%)$ & $164(18.14 \%)$ & $181(20.02 \%)$ & 904 \\
\hline Theo. (buc.) & $500(80.39 \%)$ & $53(8.52 \%)$ & $69(11.09 \%)$ & 622 \\
\hline Theo. (other) & $649(53.24 \%)$ & $328(26.91 \%)$ & $242(19.85 \%)$ & 1219 \\
\hline Theo (Id. XI) & $47(58.02 \%)$ & $23(28.40 \%)$ & $11(13.58 \%)$ & 81 \\
\hline Nonnus & $476(53.97 \%)$ & $176(19.95 \%)$ & $230(26.08 \%)$ & 882 \\
\hline
\end{tabular}

TABLE 2 - Estimations of breaks in the fourth foot of the samples analysed. Percentage of each number in its sample is shown between parentheses. ${ }^{16}$

\footnotetext{
${ }^{14}$ See Devine and Stephens (1994, 352-53) for the distinction between "accentual" and "rhythmic" clisis in Ancient Greek. Simply put, accentual clitics are atonic and tonally dependent on a lexical word, while rhythmic clitics constitute an appositive group (usually referred to as a "metrical word") with lexical words. All accentual clitics are rhythmic clitics, but not vice versa. In Ancient Greek, e.g., $\tau \varepsilon, \dot{\varepsilon} v$ and $\pi \varepsilon \rho \dot{~ a r e ~ a c c e n t u a l ~(a n d ~ r h y t h m i c) ~ c l i t i c s, ~ a n d ~} \delta \varepsilon \tilde{v} \rho \circ, \tau \tilde{\eta} \varsigma$ and $\tau o ́ v \delta \varepsilon$ are rhythmic clitics.

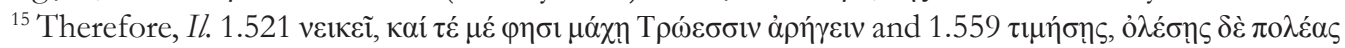

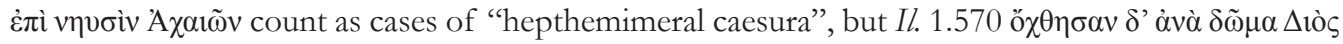

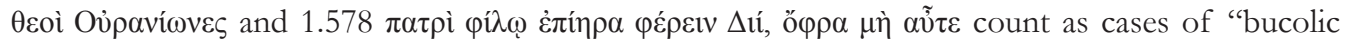
caesura". Note that the system cannot account for the fact that in 1.570 there is a stronger break

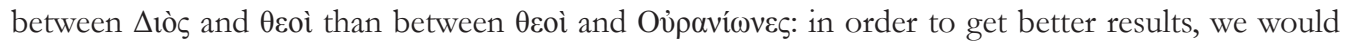
eventually need to manually input that information.

${ }^{16}$ Compare these with Van Raalte (1986, 86-87) percentages of bucolic diaeresis, based only upon the figures provided by O'Neill for words ending at position 8 (that is, at the end of the fourth foot) in the hexameter (except for Nonnus; for this poet Van Raalte analysed 150 verses himself), which do not take clisis into account:
} 
It should be noted that I have also used an estimation to identify verses without bucolic diaeresis based on the absence of words ending at the end of the fourth foot. This means that there is always a difference between the total of the tables opposing presence vs. absence of bucolic diaeresis and the total verses analysed. In order to reduce the possibility of miscalculations, I have preferred to do this instead of simply assuming that all verses in which the system does not detect a bucolic diaeresis do not have bucolic diaeresis. ${ }^{17}$

\section{INFLUENCE OF THE BREAK IN THE FOURTH FOOT ON THE QUANTITY OF THE FINAL SYLLABLE}

Table 3 is an example of the methodology used to analyse the correlation between the break in the fourth foot and the quantity of the final syllable:

\begin{tabular}{|l|c|c|c|}
\hline & Light final syllable & Heavy final syllable & \multicolumn{2}{|c|}{ Total } \\
\hline 4th with bucolic diaeresis & 162 & 438 & 600 \\
\hline 4th without bucolic diaeresis & 83 & 403 & 486 \\
\hline Total & 245 & 841 & 1086 \\
\hline
\end{tabular}

TABLE 3 - Correlation between presence of bucolic diaeresis and quantity of the final syllable in the Iliad. All final closed syllables and all final diphthongs were considered heavy (scenario B2). $\chi^{2}$ test (random distribution) $=15.1(\mathrm{p}<0.0001) ; \Omega=1.80 .{ }^{18}$

\begin{tabular}{|c|c|}
\hline & Word-end at 8 \\
\hline Iliad & $61.7 \%$ \\
\hline Odyssey & $59.0 \%$ \\
\hline Callimachus & $66.8 \%$ \\
\hline Apollonius & $61.4 \%$ \\
\hline Theocritus & $76.2 \%$ \\
\hline Nonnus & $58.0 \%$ \\
\hline
\end{tabular}

The numbers are consistently lower in my table, which is not surprising, but the only important difference in the hierarchy is in Iliad, which is in the eight position with the data used here and in the third with Van Raalte's.

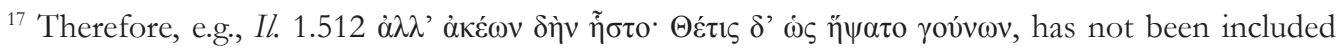
neither as a case of "verse with bucolic" nor as a case of "verse without bucolic", since there is a

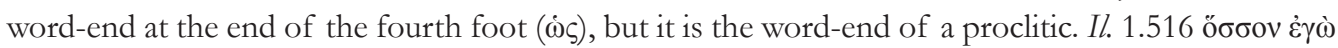

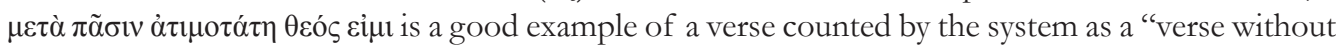

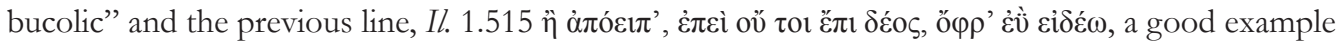
of a "verse with bucolic".

${ }^{18}$ I have always calculated $\Omega$ (the odds ratio) with the formula $(11 / 12) /(21 / 22)$, where the first digit is the row and the second digit is the column. This means that in every case $\Omega$ shows how more likely is it to find a light final syllable in the case described in the first row than in the case described in the second row. If the outcome is positive, it is more likely; if it is negative, it is less likely. See Agresti (2007, 28-30): "The odds are nonnegative, with value greater than 1.0 when a success is more likely than a failure. When odds $=4.0$, a success is four times as likely as a failure. The probability of success 
Table 4 shows the same correlation, but opposing presence of bucolic diaeresis vs. presence of hepthemimeral caesura. Surmise abbreviate.

\begin{tabular}{|l|c|c|c|}
\hline & Light final syllable & Heavy final syllable & \multicolumn{2}{|c|}{ Total } \\
\hline Bucolic diaeresis & 162 & 438 & 600 \\
\hline Hepthemimeral & 67 & 291 & 358 \\
\hline Total & 229 & 729 & 958 \\
\hline
\end{tabular}

TABLE 4 - Correlation between type of break in the fourth foot and quantity of the final syllable in the Iliad. All final closed syllables and all final diphthongs were considered heavy (scenario B2). $\chi^{2}$ test (random distribution $)=8.46(\mathrm{p}=0.0036) ; \Omega=1.61$.

In both cases, the null hypothesis that the distribution is random can be rejected at the $1 \%$ level of significance. This is also the case in all other scenarios in the analysis of Iliad (in scenario A 2 for the opposition bucolic/hepthemimeral, however, the null hypothesis can be rejected only at the $10 \%$ level of significance). The $\Omega$ values show overwhelming coherence (that is, they are close in value and always higher than 1): they range from 1.29 (scenario A3) to 1.80 (scenario B2) in the opposition bucolic/no-bucolic and from 1.30 (scenario A2) to 1.61 (scenario B2) in the opposition bucolic/hepthemimeral. This means that it is at least almost 30\% more likely to find a light heavy syllable when there is bucolic diaeresis than when there is not. In some interpretations, more than $60 \%$ more likely.

Since it would be cumbersome to present all tables produced for each poet, I have published them in an online document. However, the compiled data can be found in the appendix. Tables 5 and 6 summarize the $\Omega$ values in each text for each scenario. Italics indicate that the null hypothesis can be rejected only at the $10 \%$ level of significance, underlined indicates rejection at the $5 \%$ level of significance and bold font, rejection at the $1 \%$ level of significance.

is 0.8 , the probability of failure is 0.2 , and the odds equal $0.8 / 0.2=4.0$. We then expect to observe four successes for every one failure. When odds $=1 / 4$, a failure is four times as likely as a success. We then expect to observe one success for every four failures."

For a simple description of the $\chi^{2}$ test made by philologists (which I condense here), see Jones and Gray $(1972,192-9)$ : "A common method for measuring the difference between samples is the "chi square test'. [It] indicates how much a particular frequency $(. .$.$) deviates from some standard (...). The$ standard procedure [is] to set up [a] 'null hypothesis' (...) [and] If enough (...) criteria are found [that is, there is a significant difference between the samples], the hypothesis is rejected; otherwise it is retained." 


\begin{tabular}{|l|c|c|c|c|c|c|}
\hline & Scen. A1 & Scen. B1 & Scen. A2 & Scen. B2 & Scen. A3 & Scen. B3 \\
\hline Iliad & $\underline{1.33}$ & $\mathbf{1 . 7 0}$ & $\underline{\mathbf{1 . 3 0}}$ & $\underline{\mathbf{1 . 8 0}}$ & $\underline{1.29}$ & $\underline{\mathbf{1 . 5 8}}$ \\
\hline Odyssey & 1.00 & $\underline{1.38}$ & 1.04 & $\underline{\mathbf{1 . 5 3}}$ & 0.97 & $\underline{\mathbf{1 . 3 1}}$ \\
\hline Callimachus & 1.00 & 1.10 & 1.15 & 1.45 & 0.96 & 1.05 \\
\hline Apollonius & 1.13 & $\underline{1.45}$ & 1.18 & $\underline{\mathbf{1 . 7 1}}$ & 1.04 & 1.31 \\
\hline Theocritus (buc.) & 0.71 & 0.68 & 0.88 & 0.88 & - & - \\
\hline Theocritus (other) & 0.86 & 1.04 & 0.94 & 1.22 & - & - \\
\hline Theocritus (Id. 11$)$ & 0.83 & 0.69 & 0.86 & 0.68 & - & - \\
\hline Nonnus & 1.39 & $\underline{1.95}$ & 1.42 & $\underline{\mathbf{2 . 2 2}}$ & 1.34 & $\underline{1.76}$ \\
\hline
\end{tabular}

TABLE $5-\Omega$ values for the $2 \times 2$ tables showing the correlation between presence vs. absence of bucolic diaeresis and quantity of the final syllable by sample, with different interpretations of the quantity of the final syllable (see table 1).

\begin{tabular}{|l|c|c|c|c|c|c|}
\hline & Scen. A1 & Scen. B1 & Scen. A2 & Scen. B2 & Scen. A3 & Scen. B3 \\
\hline Iliad & $\underline{\mathbf{1 . 3 2}}$ & $\underline{\mathbf{1 . 5 6}}$ & 1.30 & $\mathbf{1 . 6 1}$ & $\underline{\mathbf{1 . 3 5}}$ & $\mathbf{1 . 5 6}$ \\
\hline Odyssey & 1.14 & $\underline{\mathbf{1 . 3 7}}$ & 1.19 & $\mathbf{1 . 5 3}$ & 1.12 & 1.31 \\
\hline Callimachus & 1.09 & 1.10 & 1.15 & 1.22 & 1.11 & 1.11 \\
\hline Apollonius & $\underline{\mathbf{1 . 7 4}}$ & 1.42 & $\underline{\mathbf{1 . 6 7}}$ & 1.47 & $\underline{\mathbf{1 . 7 2}}$ & 1.37 \\
\hline Theocritus (buc.) & 0.67 & 0.67 & 0.81 & 0.83 & - & - \\
\hline Theocritus (other) & 0.86 & 1.09 & 0.98 & 1.39 & - & - \\
\hline Theocritus (Id. 11$)$ & 0.74 & 0.78 & 0.79 & 0.80 & - & - \\
\hline Nonnus & $\underline{\mathbf{4 . 6 6}}$ & $\underline{\mathbf{6 . 6 1}}$ & $\underline{\mathbf{4 . 8 5}}$ & $\underline{\mathbf{8 . 1 5}}$ & $\underline{\mathbf{4 . 7 7}}$ & $\underline{\mathbf{8 . 3 4}}$ \\
\hline
\end{tabular}

TABLE $6-\Omega$ values for the $2 \times 2$ tables showing the correlation between presence of bucolic diaeresis vs. presence of hepthemimeral caesura and quantity of the final syllable by sample, with different interpretations of the quantity of the final syllable (see table 1).

The numbers of the Odyssey are clearly not as coherent as the ones of the Iliad. The main difference is found between scenarios with closed final syllable light (type A) and scenarios with closed final syllable heavy (type B). We can interpret the results in at least two distinct ways: on the one hand, it is possible that the only quantity that is considered in the Odyssey is the syllabic quantity; on the other, perhaps the vocalic quantity was less important for this correlation than the syllabic quantity, which is most likely rhythmic (see below). In any case, we can draw two conclusions from the $\Omega$ values of the tables of the Odyssey: first, the coherence of the $\Omega$ values in the positive outcomes with those of the Iliad suggests that, if there was a tendency, it had the same direction in both poems (combining bucolic diaeresis with light final syllable). Second, if it is real, the tendency is weaker in the second poem than in the Iliad. 
The diversity of outcomes in the Hellenistic samples is not surprising. Callimachus and Theocritus show no preferences regarding the quantity of the final syllable, ${ }^{19}$ with one peculiar coincidence: in both, scenario B2 shows less than 10\% chance of being the result of random distribution, in Callimachus in the opposition bucolic/no-bucolic and in Theocritus' non-bucolic poems in the opposition bucolic/hepthemimeral. In both cases, the direction of the preference is that shown by the Homeric poems.

Apollonius has more interesting numbers. His results are very coherent through the scenarios in the opposition bucolic/hepthemimeral, and similar to those of the Odyssey in the opposition bucolic/no-bucolic. The $\Omega$ values are higher than $1.3 \mathrm{in}$ all positive outcomes and always higher than those of the Odyssey. Of the poets studied, he is the most faithful follower of Homer.

Finally, Nonnus is by far the strictest author of the ones analysed in tables 5 and 6 (which, of course, is true in more ways than one; see Magnelli, 2016). In the opposition bucolic/no-bucolic he shows numbers similar to Homer (numbers in scenarios type A are closer to those of the Iliad, but non-significant as those of the Odyssey) and Apollonius, but in the opposition bucolic/hepthemimeral he clearly takes things to the extreme. No scenario produces an $\Omega$ value below 4.5 , which means that in his work it is at least 4.5 times more likely to find the combination bucolic diaeresis + light final syllable than to find the combination hepthemimeral + light final syllable.

\section{IDENTIFYING THE RHYTHMIC TENDENCIES}

Homer, Apollonius and Nonnus have shown a preference for combining bucolic diaeresis and light final syllable. However, we cannot be sure if that is because they actually preferred that combination, or because they preferred to avoid or use another. Since a preference for combining hepthemimeral caesura with final heavy syllable would produce the same outcome, it is necessary to verify what is happening in each case, in order to properly interpret the observed tendencies.

To do this, I have analyzed two more oppositions in each scenario: bucolic diaeresis vs. no word end in the fourth foot and hepthemimeral caesura vs. no word end in the fourth foot. By excluding one break from each analysis, we can be sure that, if there is any effect, it is being caused by the remaining one. Also, if the $\Omega$ values in both oppositions have the same sign, we will know that the effect is produced by the absence of word end in the fourth foot. In any case, though the numbers considered here are smaller, these tests should help us identify the actual rhythmic tendencies that are influencing the distribution of quantities and words in the hexameter.

The $\Omega$ values with each scenario, using the same method as in tables 5 and 6 to signal significativity, are shown in table 7.

\footnotetext{
${ }^{19}$ Fantuzzi (1995), also discovers several coincidences between these two poets, though he considers that the bucolic poems are the most Callimachean. Brioso Sánchez, 1976/7, concluded, however, that the more Callimachean poems were the "epic" Idylls.
} 


\begin{tabular}{|l|l|c|c|c|c|c|c|}
\hline & & Scen. A1 & Scen. B1 & Scen. A2 & Scen. B2 & Scen. A3 & Scen. B3 \\
\hline \multirow{2}{*}{ Iliad } & Bucolic & 1.19 & $\underline{1.61}$ & 1.20 & $\underline{\mathbf{1 . 7 6}}$ & 1.11 & 1.43 \\
& Hepth. & 0.90 & 1.03 & 0.92 & 1.10 & 0.82 & 0.92 \\
\hline \multirow{2}{*}{ Odyssey } & Bucolic & $\underline{0.70}$ & 1.16 & 0.77 & 1.36 & $\underline{0.70}$ & 1.18 \\
& Hepth. & $\underline{\mathbf{0 . 5 6}}$ & 0.85 & $\underline{0.64}$ & 0.89 & $\underline{0.62}$ & 0.90 \\
\hline \multirow{2}{*}{ Apollonius } & Bucolic & 0.90 & $\underline{\mathbf{1 . 9 1}}$ & 0.96 & $\underline{\mathbf{2 . 5 1}}$ & 0.80 & $\underline{1.64}$ \\
& Hepth. & $\underline{\mathbf{0 . 5 2}}$ & 1.34 & $\underline{0.58}$ & 1.71 & $\underline{\mathbf{0 . 4 7}}$ & 1.20 \\
\hline \multirow{2}{*}{ Nonnus } & Bucolic & 0.82 & 1.15 & 0.85 & 1.31 & 0.77 & 0.98 \\
& Hepth. & $\underline{\mathbf{0 . 1 8}}$ & $\underline{\mathbf{0 . 1 7}}$ & $\underline{\mathbf{0 . 1 8}}$ & $\underline{\mathbf{0 . 1 6}}$ & $\underline{\mathbf{0 . 1 6}}$ & $\underline{\mathbf{0 . 1 2}}$ \\
\hline
\end{tabular}

TABLE $7-\Omega$ values for the $2 \times 2$ tables showing the correlation between presence of bucolic diaeresis vs. no word end in the fourth foot and quantity of the final syllable (rows "bucolic") and the correlation between presence of hepthemimeral caesura vs. no word end in the fourth foot and quantity of the final syllable (rows "Hepth.") by sample, with different interpretations of the quantity of the final syllable (see table 1).

These numbers clearly imply that there are different tendencies in each text. In the Iliad, the only significant results are the ones in the first row: that suggests that in this poem the active tendency was a preference for the combination bucolic diaeresis + light final

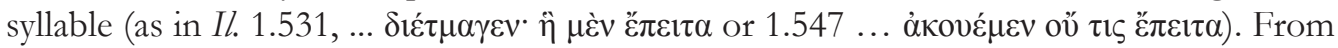
the rhythmic point of view, this seems to indicate a preference for combining a feminine break within the colon with a feminine break at the end of it. ${ }^{20}$ It could also be that the poet tried to preserve the descending rhythm produced by the bucolic diaeresis throughout the second colon. In any case, it seems likely that some sort of "rhythmic coherence" is behind these numbers. The fact that they only affect the bucolic diaeresis could be explained by its proximity to the sixth foot (which is perhaps not quite convincing) or by the fact that it is a metron diaeresis, a type of break which stichic verses tend to avoid. ${ }^{21}$

In the Odyssey, the results are highly incoherent with the ones in the previous section. Scenarios type B, which were the ones that produced significant outcomes there, are non-significant here, and the $\Omega$ values do not indicate that one tendency is stronger than the other. However, in scenarios type A, which were non-significant before, a significant tendency to avoid combining a caesura in the fourth foot with a light final syllable appears

\footnotetext{
${ }^{20}$ Accepting compositional indifference as the proper interpretation of the brevis in longo principle means that we have to deal with the rhythmic or perceptual difference between heavy and light final syllables. I have assumed that, even if the marked element in the sixth foot was always the longum (something that has been questioned by David 2006, 101-2), heavy final syllables gave the verse a stronger, more masculine ending, especially since light final syllables would have been clearly associated with the feminine break in the third foot. This assumption helps to interpret the data that I will present, but it may need to be revised when more data regarding distribution of quantities in the final syllable of different Ancient Greek metres becomes available.

${ }^{21}$ See Sicking (1993, 53 and 55).
} 
here. In other words, when we consider final closed syllables heavy, there seems to be a slight tendency to prefer the combinations bucolic + light final syllable (as in Od. 1.410 ...oíx $2 \tau \alpha$,

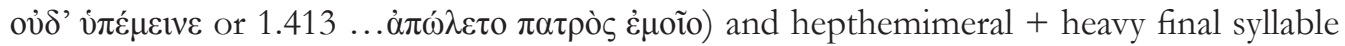

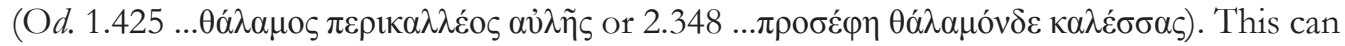
be explained using the same criteria as in the case of the Iliad (that is, rhythmic coherence within the second colon). ${ }^{22}$ However, when we consider final closed syllables light, there seems to be a tendency to prefer the combinations no word end in the fourth foot + light

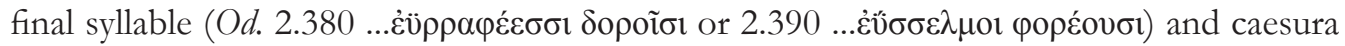
in the fourth foot + heavy final syllable. The only interpretation of this second possible outcome I can think of is that it is the result of an avoidance of the echo produced in the combination heavy final syllable in the fifth longum + heavy final syllable at the end of the

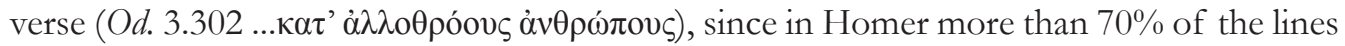
(271 out of 376) that have no word end in the fourth foot have word end in the fifth longum.

The outcomes for Apollonius suggest two conclusions: in his poetry, both caesurae shared a common preference against verses with no word end in the fourth foot (only $57 \%$ of which have word end in the fifth longum) and significant results do not help to decide if the active tendency was to combine bucolic + light final or hepthemimeral + heavy final syllable. We cannot properly interpret the first conclusion without making a decision regarding the interpretation of final closed syllables, since the sign of the $\Omega$ values changes between scenarios that consider them heavy (type B) and scenarios that consider them light (type A). On the other hand, since in every scenario the $\Omega$ value is higher in "Bucolic" than in "Hepth." - note that the lowest ratio between the values is $1.37(=1.639 / 1.198)$ for scenario B3 -, I believe that it is quite likely that in Apollonius both tendencies regarding the combination of caesura with final quantity (bucolic + light; hepthemimeral + heavy) coexisted. Apollonius takes on Homer's preference for rhythmic coherence within the second colon, and reinforces it.

Once again, Nonnus' numbers are the most peculiar. He shows no preference for the combination bucolic diaeresis + light final syllable (except for a slight non-significant one in scenarios B1 and B2), but has an extreme tendency to combine hepthemimeral with heavy final. I believe that this is not simply an adoption of the rhythmic coherence we have seen in Homer and Apollonius, but the result of an avoidance of the combination hepthemimeral + light final syllable, which, in the best case scenario (scenario A3), occurs only 7 times in Nonnus' sample. ${ }^{23}$ This avoidance is probably caused by the notable preference for heavy

\footnotetext{
${ }^{22}$ Note that the $\Omega$ value is always higher in "Bucolic" than in "Hepth." in scenarios type A too, which suggests that even in those cases there is a preference for rhythmic coherence.

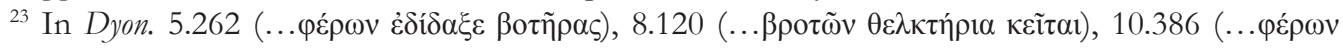

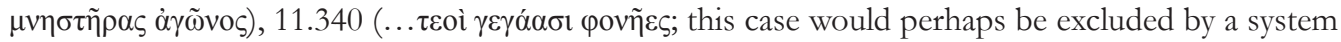

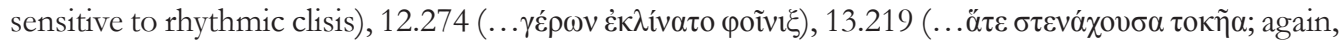

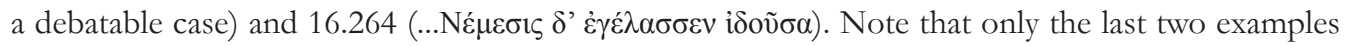
are unambiguous combinations of hepthemimeral + light final syllable, since the final syllables in the other five would be counted as heavy in at least one of the possible scenarios considered.
} 
final syllables in Nonnus: a combination hepthemimeral + light final would imply a stronger break within the second colon than at the end of it, and this seems to contradict the basic principles of this poet's hexameter.

\section{Conclusions}

While it may be possible to explain the numbers analysed in the previous sections without rejecting actual indifference of the final syllable, it seems to be unnecessary. Compositional indifference in the sixth foot does not contradict what we know about the hexameter or about Ancient Greek metrics, and it easily accounts for the results presented here. In Callimachus and Theocritus, it has led to metrical indifference regarding the correlation between the fourth and the sixth foot (we do not know - yet - if it has led to absolute metrical indifference). In Homer (at least in the Iliad) and Apollonius, however, it coexists with a tendency to produce a rhythmically coherent second colon, in which the poets preferred to combine feminine with feminine (or descending with descending) and masculine with masculine. Finally, in Nonnus, for whom we already knew compositional indifference did not lead to metrical indifference, we have found what might even be considered a new rule of his hexameter, an avoidance of the combination hepthemimeral + light final syllable, and we explained it assuming that the avoided combination emphasises too much the weaker ending in a poet that clearly preferred strong endings for his line.

As noted in the introduction, some scholars might not be convinced that the tests presented in this paper suffice to rule out actual indifference of the final syllable in the hexameter (much less in Ancient Greek poetry in general). However, the burden of proof is now in their field. Either they have to find a scenario that produces uniformly random results (none of the scenarios used here does that), or they must find another explanation for the correlations observed. If that does not happen, a whole new aspect of the hexameter (and of Ancient Greek metre in general) is open: by accepting compositional indifference as the proper interpretation of the brevis in longo principle, we need to start analysing what has each poet done with it.

\section{REFERENCES}

AGRESTI, A. An Introduction to Categorical Data Analysis. New Jersey: Wiley, 2007.

ALLEN, W. S. Correlations of Tone and Stress in Ancient Greek. In: To Honor Roman Jakobson. Den Haag: Mouton, 1967. v. 1, p. 46-62.

ALLEN, W. S. Accent and Rhythm. Cambridge: Cambridge University Press, 1973.

BRIOSO SÁNCHEZ, M. Aportaciones al estudio del hexámetro de Teócrito. Habis, v. 6, p. 21-56 y v. 7, p. 57-76, 1976/1977.

BULLOCH, A. W. A Callimachean Refinement to the Greek Hexameter. CQ, v. 2, p. 258268, 1970. 
DALE, A. M. Observations on Dactylic. WS, v. 77, p. 15-36, 1964.

DAVID, A. P. The Dance of the Muses. Choral Theory and Ancient Greek Poetics. Oxford: Oxford University Press, 2006.

DEVINE, A. M.; STEPHENS, L. D. Language and Metre. Chico, California: California Scholars Press, 1984.

DEVINE, A. M.; STEPHENS, L. D. The Prosody of Greek Speech. New York: Oxford University Press, 1994.

FANTUZZI, M. Variazione sull'esametro in Teocrito. In: FANTUZZI, M.; PRETAGOSTINI, R. (Ed.) Struttura e storia dell'esametro greco. Roma: Gruppo Editoriale Internazionale, 1995. v. I, p. 221-264.

IRIGOIN, J. Colon, vers et période (à propos d'un choeur des Núees d'Aristophane). In:

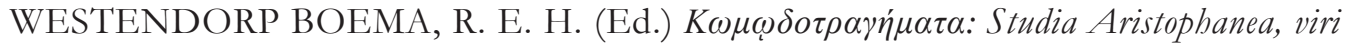
Aristophanei W.J. W. Koster in honorem. Amsterdam, 1967. p. 65-73.

JONES, F. P.; GRAY, F. E. Hexameter Patterns, Statistical Inference and the Homeric Question: An Analysis of the La Roche Data. TAPhA, v. 103, p. 187-209, 1972.

KORZENIEWSKI, D. Griechische Metrik. Darmstadt: Wissenschaftliche Buchgesellschaft, 1968.

LEEDY, D. Singing Ancient Greek: A Guide to Musical Reconstruccion and Performance, eScholarship (<http://escholarship.org/uc/item/1rj4j3n1>), 2014.

LUQUE MORENO, J. Hexámetros especiales. RELat, v. 5, p. 117-145, 2005.

MAAS, P. Greek Metre, trans. H. Lloyd-Jones. Oxford: Clarendon Press, 1962.

MAGNELLI, E. The Nonnian Hexameter. In: ACCORINTI, D. (Ed.) Brill's Companion to Nonnus of Panopolis. Leiden: Brill, 2016. p. 353-371.

NAGY, G. Pindar's Homer: The Lyric Possession of an Epic Past. Baltimore: Johns Hopkins University Press, 1990.

O’NEILL Jr., E. G. The Localization of Metrical Word Types in the Greek Hexameter. YClS, v. 8, p. 103-178, 1942.

RYAN, K. M. Gradient syllable weight and weight universals in quantitative metrics. Phonology, v. 28, p. 413-454, 2011.

SICKING, C. M. J. Griechische Verslehre. München: C. H. Beck, 1993.

SMYTH, H. W. A Greek Grammar for Colleges. New York: American Book Company, 1956.

Van RAALTE, M. Rhythm and Metre. Towards a Systematic Description of Greek Stichic Verse. Assen: Van Gorcum, 1986.

WEST, M. L. Greek Metre. Oxford: Oxford University Press, 1982. 


\section{APPENDIX}

Since it would be cumbersome to include every table produced for this study, but the data should be available for its consultation, I have included in this appendix two tables, each with the number of verses with heavy or light syllables with different types of fourth foot by scenario and by poet. The first table shows number of verses with bucolic diaeresis and without bucolic diaeresis (see sec. 2 for the meaning of "without bucolic"). The second table shows the number of verses with bucolic diaeresis, with hepthemimeral and with no word end in the fourth foot. I have included a column "total" in each table: note that it adds up the verses considered in each table, not the total number of verses in the sample.

\begin{tabular}{|c|c|c|c|c|c|c|}
\hline \multirow{2}{*}{ Sample } & \multirow{2}{*}{ Scenario } & \multicolumn{2}{|c|}{ Bucolic diaeresis } & \multicolumn{2}{|c|}{ No bucolic diaeresis } & \multirow{2}{*}{ Tota } \\
\hline & & Heavy final & Light Final & Heavy final & Light Final & \\
\hline \multirow[t]{6}{*}{ Iliad } & Scenario A1 & 290 & 310 & 269 & 217 & \multirow[t]{6}{*}{1086} \\
\hline & B1 & 404 & 196 & 378 & 108 & \\
\hline & $\mathrm{A} 2$ & 324 & 276 & 294 & 192 & \\
\hline & $\mathrm{B} 2$ & 438 & 162 & 403 & 83 & \\
\hline & A3 & 272 & 328 & 251 & 235 & \\
\hline & B3 & 386 & 214 & 360 & 126 & \\
\hline \multirow[t]{6}{*}{ Odyssey } & Scenario A1 & 299 & 335 & 224 & 251 & \multirow[t]{6}{*}{1109} \\
\hline & B1 & 428 & 206 & 352 & 123 & \\
\hline & $\mathrm{A} 2$ & 301 & 333 & 254 & 221 & \\
\hline & $\mathrm{B} 2$ & 462 & 172 & 382 & 93 & \\
\hline & A3 & 279 & 355 & 206 & 269 & \\
\hline & B3 & 408 & 226 & 334 & 141 & \\
\hline \multirow[t]{6}{*}{ Callimachus } & Scenario A1 & 290 & 284 & 156 & 153 & \multirow[t]{6}{*}{883} \\
\hline & B1 & 413 & 161 & 228 & 81 & \\
\hline & $\mathrm{A} 2$ & 335 & 239 & 191 & 118 & \\
\hline & $\mathrm{B} 2$ & 458 & 116 & 263 & 46 & \\
\hline & A3 & 269 & 305 & 142 & 167 & \\
\hline & B3 & 392 & 182 & 214 & 95 & \\
\hline \multirow[t]{6}{*}{ Apollonius } & Scenario A1 & 190 & 355 & 112 & 186 & \multirow[t]{6}{*}{843} \\
\hline & B1 & 362 & 183 & 221 & 77 & \\
\hline & $\mathrm{A} 2$ & 226 & 319 & 136 & 162 & \\
\hline & $\mathrm{B} 2$ & 398 & 147 & 245 & 53 & \\
\hline & A3 & 176 & 369 & 99 & 199 & \\
\hline & B3 & 348 & 197 & 208 & 90 & \\
\hline \multirow{4}{*}{$\begin{array}{l}\text { Theocritus } \\
\text { (buc.) }\end{array}$} & Scenario A1 & 281 & 196 & 51 & 50 & \multirow[t]{4}{*}{578} \\
\hline & B1 & 362 & 115 & 69 & 32 & \\
\hline & A2 & 311 & 166 & 63 & 38 & \\
\hline & $\mathrm{B} 2$ & 392 & 85 & 81 & 20 & \\
\hline \multirow{4}{*}{$\begin{array}{l}\text { Theocritus } \\
\text { (other) }\end{array}$} & Scenario A1 & 313 & 298 & 227 & 251 & \multirow[t]{4}{*}{1089} \\
\hline & $\mathrm{B} 1$ & 462 & 149 & 365 & 113 & \\
\hline & A2 & 342 & 269 & 260 & 218 & \\
\hline & B2 & 491 & 120 & 398 & 80 & \\
\hline
\end{tabular}




\begin{tabular}{|c|c|c|c|c|c|c|}
\hline \multirow{4}{*}{$\begin{array}{l}\text { Theocritus } \\
\text { (Id. 11) }\end{array}$} & Scenario A1 & 19 & 22 & 10 & 14 & \multirow{4}{*}{65} \\
\hline & B1 & 29 & 12 & 15 & 9 & \\
\hline & A2 & 22 & 19 & 12 & 12 & \\
\hline & $\mathrm{B} 2$ & 32 & 9 & 17 & 7 & \\
\hline \multirow[t]{6}{*}{ Nonnus } & Scenario A1 & 401 & 66 & 354 & 42 & \multirow[t]{6}{*}{863} \\
\hline & B1 & 419 & 48 & 374 & 22 & \\
\hline & $\mathrm{A} 2$ & 409 & 58 & 360 & 36 & \\
\hline & B2 & 427 & 40 & 380 & 16 & \\
\hline & A3 & 390 & 77 & 345 & 51 & \\
\hline & B3 & 408 & 59 & 366 & 30 & \\
\hline
\end{tabular}

\begin{tabular}{|c|c|c|c|c|c|c|c|c|}
\hline \multirow{2}{*}{ Sample } & \multirow{2}{*}{ Scenario } & \multirow{2}{*}{\multicolumn{2}{|c|}{$\begin{array}{c}\text { Bucolic diaeresis } \\
\text { Heavy final } \\
\text { Light Final }\end{array}$}} & \multirow{2}{*}{\multicolumn{2}{|c|}{\begin{tabular}{|c|} 
Hepthemimeral \\
Heavy final $:$ Light Final
\end{tabular}}} & \multicolumn{2}{|c|}{ No word end on 4th } & \multirow{2}{*}{ Total } \\
\hline & & & & & & Heavy final ! & Light Final & \\
\hline \multirow{6}{*}{ Iliad } & Scenario A1 & 290 & 310 & 198 & 160 & 100 & 90 & \multirow[t]{6}{*}{1148} \\
\hline & B1 & 404 & 196 & 273 & 85 & 146 & 44 & \\
\hline & $\mathrm{A} 2$ & 324 & 276 & 216 & 142 & 111 & 79 & \\
\hline & B2 & 438 & 162 & 291 & 67 & 157 & 33 & \\
\hline & A3 & 272 & 328 & 189 & 169 & 91 & 99 & \\
\hline & B3 & 386 & 214 & 264 & 94 & 137 & 53 & \\
\hline \multirow[t]{6}{*}{ Odyssey } & Scenario A1 & 299 & 335 & 180 & 159 & 69 & 108 & \multirow[t]{6}{*}{1150} \\
\hline & B1 & 428 & 206 & 264 & 93 & 128 & 53 & \\
\hline & A2 & 301 & 333 & 203 & 154 & 83 & 98 & \\
\hline & $\mathrm{B} 2$ & 462 & 172 & 287 & 70 & 142 & 39 & \\
\hline & A3 & 279 & 355 & 167 & 190 & 64 & 117 & \\
\hline & B3 & 408 & 226 & 251 & 106 & 123 & 58 & \\
\hline \multirow[t]{6}{*}{ Callimachus } & Scenario A1 & 290 & 284 & 95 & 85 & 56 & 64 & \multirow[t]{6}{*}{874} \\
\hline & B1 & 413 & 161 & 133 & 47 & 83 & 37 & \\
\hline & A2 & 335 & 239 & 111 & 69 & 74 & 46 & \\
\hline & B2 & 458 & 116 & 149 & 31 & 101 & 19 & \\
\hline & A3 & 269 & 305 & 89 & 91 & 49 & 71 & \\
\hline & B3 & 392 & 182 & 127 & 53 & 76 & 44 & \\
\hline \multirow[t]{6}{*}{ Apollonius } & Scenario A1 & 190 & 355 & 79 & 85 & 48 & 100 & \multirow[t]{6}{*}{857} \\
\hline & B1 & 362 & 183 & 121 & 43 & 117 & 31 & \\
\hline & A2 & 226 & 319 & 89 & 75 & 60 & 88 & \\
\hline & B2 & 398 & 147 & 131 & 33 & 129 & 19 & \\
\hline & A3 & 176 & 369 & 74 & 90 & 41 & 107 & \\
\hline & B3 & 348 & 197 & 116 & 48 & 110 & 38 & \\
\hline
\end{tabular}




\begin{tabular}{|c|c|c|c|c|c|c|c|c|}
\hline \multirow{4}{*}{$\begin{array}{l}\text { Theocritus } \\
\text { (buc.) }\end{array}$} & Scenario A1 & 281 & 196 & 26 & 27 & 22 & 20 & \multirow[t]{4}{*}{572} \\
\hline & B1 & 362 & 115 & 36 & 17 & 30 & 12 & \\
\hline & A2 & 311 & 166 & 32 & 21 & 25 & 17 & \\
\hline & B2 & 392 & 85 & 42 & 11 & 33 & 9 & \\
\hline \multirow{4}{*}{$\begin{array}{l}\text { Theocritus } \\
\text { (other) }\end{array}$} & Scenario A1 & 313 & 298 & 156 & 172 & 90 & 96 & \multirow[t]{4}{*}{1125} \\
\hline & B1 & 462 & 149 & 253 & 75 & 135 & 51 & \\
\hline & A2 & 342 & 269 & 182 & 146 & 99 & 87 & \\
\hline & B2 & 491 & 120 & 279 & 49 & 144 & 42 & \\
\hline \multirow{4}{*}{$\begin{array}{l}\text { Theocritus } \\
\text { (Id. 11) }\end{array}$} & Scenario A1 & 19 & 22 & 9 & 14 & 2 & 3 & \multirow[t]{4}{*}{69} \\
\hline & $\mathrm{B} 1$ & 29 & 12 & 15 & 8 & 2 & 3 & \\
\hline & A2 & 22 & 19 & 11 & 12 & 2 & 3 & \\
\hline & B2 & 32 & 9 & 17 & 6 & 2 & 3 & \\
\hline \multirow[t]{6}{*}{ Nonnus } & Scenario A1 & 401 & 66 & 170 & 6 & 175 & 35 & \multirow[t]{6}{*}{853} \\
\hline & $\mathrm{B} 1$ & 419 & 48 & 173 & 3 & 191 & 19 & \\
\hline & A2 & 409 & 58 & 171 & 5 & 180 & 30 & \\
\hline & $\mathrm{B} 2$ & 427 & 40 & 174 & 2 & 196 & 14 & \\
\hline & A3 & 390 & 77 & 169 & 7 & 167 & 43 & \\
\hline & B3 & 408 & 59 & 173 & 3 & 183 & 27 & \\
\hline
\end{tabular}

Recebido em: 29/09/2017 